https://doi.org/10.33416/baybem.1009031

İşletme Ekonomi ve Yönetim Araştırmaları Dergisi

(The Journal of Business, Economics and Management Research) Y11 2022 / Say1: 1 / 47 - 61

Araştırma Makalesi / Research Article

Gönderilme Tarihi: 13 Ekim 2021; Revize Edilmiş Hali: 10 Kasım 2021; Kabul Tarihi: 25 Kasın 2021

\title{
TURKEY'S BRAND VALUE AND COUNTRY IMAGE IN THE EYES OF AZERBAIJAN BEFORE AND AFTER THE RECENT AZERBAIJAN ARMENIA
}

\section{WAR}

\author{
Bora GÖKTAŞ ${ }^{1}$ \\ İnci ERDOĞAN TARAKÇI² \\ Mehmet BAŞ ${ }^{3}$
}

ABSTRACT

The concept of brand continues to show its function in different areas and increase its importance day by day. Especially in the intense global competition environment, branding has moved from the dimension of products to a dimension between cities and countries. A strong country brand reflects on the products produced by the country, on the other hand, it increases the reputation of the country and enables it to have more say in the international political arena and to become a centre of attraction for investors by increasing their income. In this study, it is aimed to be determined whether Turkey's brand value and country image in the eyes of the brother country Azerbaijan has been changed or not as a result of the support given to Azerbaijan by Turkey in the recent Azerbaijan-Armenia war. For this purpose, the first period of the study in September 2020, and the second period after the war between December 2020 and January 2021, was carried out by conducting an online survey throughout Azerbaijan with Azerbaijani Turks living in Azerbaijan. Study findings reveal the brand value and country image of Turkey before and after the war in the eyes of Azerbaijani Turks living in Azerbaijan in dimensions of sincerity, excitement, competence, sophistication and ruggedness.

Keywords: Brand, Country Brand, The Turkish World, Azerbaijan, Turkey.

\section{SON AZERBAYCAN-ERMENISTAN SAVAŞI ÖNCESI VE SONRASI AZERBAYCAN'IN GÖZÜNDE TÜRKIYE'NIN MARKA DEĞERİ VE ÜLKE IMMAJI}

\section{ÖZ}

Marka kavramı her geçen gün işlevini farklı alanlarda göstermeye ve önemini arttırmaya devam etmektedir. Özellikle yoğun küresel rekabet ortamında markalaşma ürünler boyutundan şehirler ve ülkeler arası bir boyuta taşınmıştır. Gü̈çlü bir ülke markası, ülkenin ürettiği ürünlerine de yansırken diğer yandan ülkenin itibarını arttırarak uluslararası siyasi arenada daha fazla söz sahibi olmasını ve gelirlerini arttırarak yatırımcılar için cazibe merkezi haline gelmesini sağlamaktadır. Bu çalışmada, yakın zamanda yaşanılan Azerbaycan-Ermenistan savaşında Türkiye'nin Azerbaycan'a vermiş olduğu destek neticesinde, kardeş ülke Azerbaycan'ın gözünden Türkiye'nin marka değerinin ve ülke imajının değişip değişmediği belirlenmeye çalışılmıştır. Bu amaçla Eylül 2020'de çalışmanın ilk dönemi, Aralık 2020-Ocak 2021 tarih aralığında ise savaş sonrası ikinci dönemi Azerbaycan genelinde Azerbaycan'da yaşayan Azeri Türkleri ile çevrimiçi anket çalışması yapılarak gerçekleştirilmiştir. Çalışma bulguları Azerbaycan'da yaşayan Azeri Türklerinin gözünden Türkiye'nin marka değerini ve ülke imajını savaş öncesi ve sonrasında samimiyet, coşkunluk, yetkinlik, seçkinlik ve sağlamlık boyutlarında ortaya koymaktadır.

Anahtar Kelimeler: Marka, Ülke Markası, Türk Dünyası, Azerbaycan, Türkiye.

\footnotetext{
${ }^{1}$ Doç.Dr., boragoktas@gmail.com, Bayburt Üniversitesi, 0000-0003-2159-0241

2 Doç.Dr., inci.erdgn@hotmail.com, Bilecik Şeyh Edebali Üniversitesi, 0000-0002-4101-7111

3 Prof.Dr., mehmet.bas@hbv.edu.tr, Hacı Bayram Veli Üniversitesi, 0000-0002-5443-7617
} 


\section{INTRODUCTION}

As a result of the industrialization that started with the industrial revolution and the spread of mass production, local products started to be replaced by packaged products and factories began to put a number of special symbols and signs on their products in order to distinguish them from others. After a while, companies that became cumbersome and faced difficulties in terms of costs started to search for cost reduction methods and turned to cheap labour force from foreign countries as the most practical solution to this problem. Thus, the importance given to production was replaced by marketing and brand image (İnanç and Yacan 2018: 318).

The brand concept has functionality in many areas. As a result of the stabilization of globalization, industrialization has created a competitive environment in both local and international markets. This competitive growth has turned from the dimension of products to an intercity and even inter-country dimension. Thus, the view that countries are also brands has emerged (pazarlama30.com). As a result of this change, it has become more valuable to have a strong brand image with fewer goods and employees, and the products branded after being produced in third world countries have started to be sold at much higher prices in these countries. Although local companies produce products of similar quality and design, they have become unable to compete with their global competitors who have a strong brand image. The solution for countries to protect their local brands and to cope with global competition is the branding of the region or country. Today, competition is experienced across countries, and the brand values and images of countries are also reflected in their products.

Considering the global competition, countries turn to branding efforts and make investments in this field so that the products they produce can outperform their strong competitors in international markets. The concept of country branding, which increases its importance day by day, nowadays enables to gain more voice in the international political arena with to the reputation it has brought to the country by exceeding its marketing objectives. At the same time, it makes the country a centre of attraction for investors with the increase in the country's income, especially in tourism. For this reason, being a brand for countries has become a more important issue than producing products (Dündar Kurtuluş 2008: 286, from Feldwick 2002).

Country branding is an important issue that needs to be addressed due to the opportunities and advantages it creates. In this study, it is aimed to be determined whether Turkey's brand value and country image in the eyes of the brother country Azerbaijan has been changed or not as a result of the support given to Azerbaijan by Turkey in the recent Azerbaijan-Armenia war. If it changed, it is investigated in which direction it changed.

\section{AZERBAIJAN-TURKEY RELATIONS}

Until 1991, when Azerbaijan was under the control of the Soviet Union, the relationship between the two countries was very limited. At that time, the basis of relationships was at the level of longing (Aslanl1 2012: 177). However, with the collapse of the Soviet Union, relations gained momentum. The first state to recognize the independence of Azerbaijan has been Turkey. The Republic of Azerbaijan 
declared its independence on 30 August 1991 and Turkey recognize the independence on November 9, 1991. Diplomatic relations were established on January 14, 1992, and the representative of Turkey, who serves as the consul general in Baku, was elevated to the level of an embassy (http://www.mfa.gov.tr/turkiye-azerbaycan-siyasi-iliskileri.tr.mfa). Thus, the relations between the two brother countries have always developed positively, with some minor exceptions. Political relations have entered a hot period, social and cultural relations have increased and significant investments have been made by Turkish investors to Azerbaijan (Mesimov 2001: 274).

Azerbaijan-Turkey relations have very old historical roots and are developed on the basis of mutual initiative and unwavering will. When we look at the early periods of the 20th century, we see that Azerbaijanis and Turks always stood shoulder to shoulder with the difficulties they faced, and they went through heavy tests together (Veliyev et al. 2012: 9). Strategic relations, whose foundations began to be strengthened especially at the beginning of the 20th century, were carried to the next level with the steps and decisions taken at the end of the 20th century and the beginning of the 21 st century. With the comprehensive Strategic Partnership and Mutual Support Agreement signed on 16 August 2010, this feature of the relations was deepened. With the signing of the Joint Declaration on the establishment of the High Level Strategic Cooperation Council between the two countries on September 15, 2010, a different dimension was added to the strategic relations. Due to the nature of Azerbaijan-Turkey relations (priority of historical, cultural, national and religious ties) it is known that the political, military and cultural aspects of the relations are the centre of attention more. Thus, the strategic dimension of the relations between the two countries is getting stronger (Aslanl1 2018: 24). The strategic partnership of the relations between the two countries (beyond historical, cultural and linguistic proximity) is also related to the harmonization of foreign policy goals in many issues in the region. Both countries have a common strategic goal regarding the region and there is no serious conflict in their foreign policy interests. In fact, they are in harmony with each other in foreign policy on many issues. These are, no doubt, is a reason to say that Turkey-Azerbaijan relations are at the level of strategic partnership (Veliyev 2020: 20). BTC oil pipeline, BTE gas pipeline and BTK railway project are important projects that lead Azerbaijan and Turkey in to strategic cooperation. Both countries have gained economic benefits through these projects, besides; a security corridor has been established in the Caucasus (Karadağ and Top 2012: 6).

Turkey and Azerbaijan are two important countries of Eurasia. Due to the ethnic, religious and cultural ties between them, these countries define each other as brother states. Therefore, there is a special link between these two countries. Due to the lineage between them, the two states see each other as brother countries, whether at the official level or among the people. In this sense, relations between Turkey and Azerbaijan outside the scope of conventional international relations based on the priority of the state have a special dimension. The words of the Great Leader Mustafa Kemal Atatürk "The joy of Azerbaijan is our joy, its sorrow is our sorrow" and President Heydar Aliyev's statement "We are one nation, two states" expresses the aforementioned bonds of brotherhood (Aydın 2018: 39). 


\section{BRAND, COUNTRY BRANDING AND HYPOTHESES}

In the global economic system, the concepts of brand and branding emerge as an inevitable result of competition. Brand is; the name, term, word, symbol, design, sign, shape, color or various combinations of these are used to identify, promote and differentiate the goods and services of one or a group of producers and / or sellers from those of their competitors (Baş 2020: 35, Kotler 2006). Branding is an expression of a process (İnanç and Yacan 2018: 318). Brand provides an increase of consumer satisfaction in shopping and protects the consumer rights. It also provides stability in sales and protects the permanence of companies in the market (Aslan and Özbeyaz 2019: 1971-1972). With these elements that distinguish it from others, the product becomes a brand as it is accepted in the market and creates a unique field. With the application of corporate branding techniques to cities and countries, the concept of branding has moved from products to cities and countries, and the concept of country branding has emerged.

The first successful country branding example of Turkey's history is the branding studies carried out by Fatih Sultan Mehmed after the conquest of Istanbul (Aksoy 2008: 3). Fatih Sultan Mehmed not only wanted to conquer Istanbul, a city that entered the dreams of the Prophet, but to have the soul of the city. With this perseverance, he took the Byzantine commanders and court officials who had fought with him and added them to the Ottoman Empire. And to build a new civilization he created a cosmopolitan lifestyle that everyone exemplified and envied by creating a new culture with Ottoman, Byzantine, Genoese, Turkish, Armenian, Jewish, Greek, Kurdish, Arab, Levantine and others (Aksoy 2008: 4, from Altan 2006).

The second deep-rooted branding activity after Fatih was carried out by Gazi Mustafa Kemal Atatürk (Aksoy 2008: 4). Atatürk, with his radical reforms and revolutions, brought a new identity and lifestyle at the level of contemporary civilizations by drawing a road map again to this nation that has just emerged from war and is in poverty.

Another concept that emerged in the process of branding of countries is the image of the country. Image is the perception formed as a result of a series of informing processes (Özenç 2002: 38). In other words, image is the perception of symbols related to all the values of a person, institution, object or country in the short and long term (Gültekin 2005: 127). Therefore, image is a dynamic concept that develops over time and constantly changes in the light of information obtained from different channels, messages transmitted, culture, relationships and prejudices. Country image, on the other hand, emerges as an indicator of the perception and impression created by a country in both national and international arena. Country image is the general quality perceived by the consumer for a particular country and products belonging to that country. In other words, it is a general expression of the way a country is perceived by other countries, the perception it creates in a global context, the dignity and respect it has, the support it can receive in its global activities and the sympathy it can create on other countries (Gültekin 2005: 127). A strong country image that a nation will have is the most important factor that determines its interests in the international political arena with its impact on other countries, which is as 
important as its cultural values, economic conditions, social infrastructure and military power. Each country has identified with different icons along with its historical culture and created a country image by branding (Onay 2008: 107).

Perception towards a particular nation strongly influences behaviour towards that country. In particular, Aaker's (1997) psychological theory developed to measure brand personality is frequently used to measure country image. Dimensions in this scale are; excitement, sincerity, sophistication, competence, and ruggedness (Chiang and Yang 2018:179). Originally developed for product brands, this scale has been used for country brands after a while. Aaker's scale can reflect intentions towards a country (Méndez et al. 2013: 1029). Thus, Aaker's brand personality scale is applied in the context of city and country image (Priporas et al. 2020: 455). Because, according to the literature, brand personality is also "a set of characteristics associated with a particular country". Aaker's original scale developed in the USA has been found to have some international applicability in studies conducted for Spanish and Japanese countries (Pitt et al. 2007: 837). Starting from here, the hypotheses developed by considering Aaker's (1997) 5 brand dimensions are as follows:

H1: Turkey's image in the eyes of the Azerbaijani people showed a significant difference in a positive (increased) direction after the war for sincerity" dimension.

H2: Turkey's image in the eyes of the Azerbaijani people showed a significant difference in a positive (increased) direction after the war for "excitement" dimension.

H3: Turkey's image in the eyes of the Azerbaijani people showed a significant difference in a positive (increased) direction after the war for "competence" dimension.

H4: Turkey's image in the eyes of the Azerbaijani people showed a significant difference in a positive (increased) direction after the war for "sophistication" dimension.

H5: Turkey's image in the eyes of the Azerbaijani people showed a significant difference in a positive (increased) direction after the war for "ruggedness" dimension.

H6: Turkey's image in the eyes of the Azerbaijani people showed a significant difference in a positive (increased) direction after the war for the "brand image" scale.

\section{METHODOLOGY}

\subsection{Purpose of the Research}

At the beginning of the study, it is aimed to determine Turkey's brand value and country image in the eyes of the brother country Azerbaijan. For this purpose, as of September 4, 2020, an online survey study was started to be implemented with Azerbaijani Turks living in Azerbaijan throughout Azerbaijan. However, with the start of the war between Azerbaijan and Armenia, the survey study was terminated due to restrictions on internet access throughout Azerbaijan. With the end of the war in favour of Azerbaijan, internet access was put into service again and it was decided to continue where it left off. Thus, the purpose of the research has been reconstructed as to determine whether Turkey's brand value and country image in the eyes of the brother country Azerbaijan has been changed or not as a result of the support given to Azerbaijan by Turkey in the recent Azerbaijan-Armenia war. 


\subsection{Research Method, Universe and Sample}

In order to achieve the purpose of the study, the questionnaire of the research, which was previously created and put into practice, was adapted to be applied again to the same participants by adding 1 question and changing the premise. Of the participants who completed the survey in September 2020 were asked to complete the questionnaire again and it has been explained to the participants that the purpose of the study is to determine whether Turkey's brand value and country image has change or not after the Azerbaijan-Armenia war and the questionnaire was re-administered to the same participants with 1 question added to the survey ("Did you participated in the survey in September 2020 period? If the answer is yes continue to survey, if no end the survey").

The first period of the survey is September 2020; the second term was held between December 2020 and January 2021. The questionnaire form prepared for the study was applied to 378 people on www.surveey.com in September 2020; Afterwards, it was sent again through the same channels with a re-adapted version (adding a question item to enable those who previously filled out the questionnaire to fill in again) between December 2020 and January 2021, and the same people were asked to fill out again. This time, 335 people returned to the questionnaire and it was assumed that this number was sufficient for benchmarking analysis.

For the sample selection of the study, due to the fact that the survey will be carried out in Azerbaijan and the pandemic, in the first part, the "convenience sampling method" was applied, and in the second part, the same sample group was asked to fill it again. The obtained data set was tested in SPSS 25 package program. Approval was obtained for the questionnaire by the Bayburt University Ethics Committee on September 4, 2020.

The survey of the research consists of two parts. The first part consists of 6 demographic questions and the second part consists of 5-point Likert-type scale items (5: strongly agree, 1: strongly disagree). For the expressions in Likert scale, inspired by the "brand personality" scale created by Aaker in 1997 and the studies of Maruitti and Giraldi (2020) and Queiroz and Giraldi (2015), a total of 50 items, 11 for "sincerity", 10 for "excitement", 13 for "competence", 8 for "sophistication" and 8 for "ruggedness" were directed to the participants, thus the questionnaire consisted of 56 questions. In the study, three scale items were asked in reverse to replace the control question.

\subsection{Limitations of the Study}

As the constraints of the research;

$\checkmark$ In the first period of the study (pre test), 378 questionnaires and in the second period 335 questionnaires were evaluated (post test). The sample size could not be increased due to the war that broke out in Azerbaijan and therefore it was assumed that the number of data accessed was sufficient. In terms of generalizability and reliability of the study, the most important limitation of the study is that no more participants could be reached.

$\checkmark$ The second constraint of the study is about the scale used. In order to achieve the purpose of the study, "brand personality" scale of Aaker, which is one of the most used scales 
in the relevant subject, was used. By using different scales, scale items can be enriched and thus more expressions can be directed to the participants. On the other hand, it should not be forgotten that using different scales may cause propositions to shift to different factors in factor analysis performed in SPSS. If more statements are directed to the participants; although it helps to obtain more information, it can also cause the participant to get bored of answering the questionnaire and to respond without reading. This means that the data obtained from the research are unhealthy.

$\checkmark$ A third constraint is that the 378 questionnaires reached in the first period cannot be reached again. However, reaching this number in the same way is a very difficult possibility. The researchers tried to reach this number as much as possible and for this, the duration of the second period of the survey was approximately 2 months. The first implementation period lasted 24 days, and afterwards, the survey had to be terminated due to the restriction of internet access due to the war. Due to these limitations, the number of data remained 335 and it was assumed that this number was sufficient.

A final constraint is that the sample was determined using the "convenience sampling method". This method was chosen due to the fact that the study took place in Azerbaijan and the Covid-19 pandemic. It is appropriate to choose random sampling methods in order to reach more generalizable and reliable results.

\subsection{Research Reliability}

For the reliability of the study, Cronbach's Alpha Coefficient should be between 0.81-1.00 (0.81 $\leq \alpha \leq 1.00$ ) to be considered highly reliable (Kılıç 2016: 48). In this study, Cronbach's Alpha value was examined for both survey applications. This value is 0.967 for the September 2020 period survey (pre test); It was 0.869 for the period December 2020-January 2021 (post test).Accordingly, the reliability of both questionnaires can be considered high. Results are presented in Table 1.

Table 1. Reliability of the Research Scale

\begin{tabular}{|l|c|c|}
\hline Period & Cronbach's Alpha Coefficient & Number of Items \\
\hline Pre Test & .967 & 50 \\
\hline Post Test & .869 & 50 \\
\hline
\end{tabular}

\subsection{Factor Analysis Related to Research}

In the factor analysis, the KMO value for the pre test is 0.893 ; Bartlett's Test of Sphericity value is 281.33 and p value is 0.000 . The KMO value for the post test is 0.885 ; Bartlett's Test of Sphericity value is 132.714 and $\mathrm{p}$ value is 0.000 .

According to these results, the sample size is sufficient and suitable for factor analysis. Dimensions created in the research consisted of five dimensions in accordance with the original scale. 
These dimensions are "sincerity", "excitement", "competence", "sophistication" and "ruggedness". Table 2 shows the factor loads of the scale items. The scale explains $74.604 \%$ of the total variance.

Table 2. Factor Loads of Scale Items

\begin{tabular}{|c|c|c|}
\hline DIMENSION & ITEM & FACTOR LOAD \\
\hline \multirow{11}{*}{ SINCERITY } & Turkey is a sincere country & .817 \\
\hline & Turkey is an honest country & .941 \\
\hline & Turkey is an original country & .849 \\
\hline & Turkey is a friendly country & .865 \\
\hline & Turkey is an ordinary country (inverted scale) & .868 \\
\hline & Turkey is a cheerful country & .853 \\
\hline & Turkey is a wholesome countries & .796 \\
\hline & Turkey is a family-oriented country & .875 \\
\hline & Turkey is a realistic country & .854 \\
\hline & Turkey is a virtuous countries & .950 \\
\hline & Turkey is a sentimental country & .941 \\
\hline \multirow{10}{*}{ EXCITEMENT } & Turkey is an imaginative (creative) country & .891 \\
\hline & Turkey is a young country & .781 \\
\hline & Turkey is an exciting country & .911 \\
\hline & Turkey is a trending country & .959 \\
\hline & Turkey is a spirited country & .674 \\
\hline & Turkey is a contemporary country & .862 \\
\hline & Turkey is a coward country (inverted scale) & .842 \\
\hline & Turkey is a unique country & .841 \\
\hline & Turkey is an independent country & .752 \\
\hline & Turkey is an up-to-date country & .900 \\
\hline \multirow{9}{*}{ COMPETENCE } & Turkey is a charismatic country & .594 \\
\hline & Turkey is a successful country & .851 \\
\hline & Turkey is a leader country & .961 \\
\hline & Turkey is a respectable country & .869 \\
\hline & Turkey is a valuable country & .840 \\
\hline & Turkey is a reliable country & .769 \\
\hline & Turkey is a confident country & .848 \\
\hline & Turkey is a hard working country & .887 \\
\hline & Turkey is a secure country & .988 \\
\hline
\end{tabular}




\begin{tabular}{|c|c|c|}
\hline & Turkey is an intelligent country & .988 \\
\hline & Turkey is a technical country & .806 \\
\hline & Turkey is a corporate country & .926 \\
\hline & Turkey is a responsible country & .917 \\
\hline \multirow{8}{*}{ SOPHISTICATION } & Turkey is a rough country (inverted scale) & .788 \\
\hline & Turkey is a good looking country & .777 \\
\hline & Turkey is an ambitious country & .801 \\
\hline & Turkey is an upper class country & .806 \\
\hline & Turkey is a charming country & .862 \\
\hline & Turkey is a glamorous country & .862 \\
\hline & Turkey is a smooth country & .885 \\
\hline & Turkey is a feminine country & .919 \\
\hline \multirow{8}{*}{ RUGGEDNESS } & Turkey is a struggling country & .677 \\
\hline & Turkey is a masculine country & .856 \\
\hline & Turkey is a tough country & .842 \\
\hline & Turkey is a western country & .715 \\
\hline & Turkey is a strong country & .822 \\
\hline & Turkey is an outdoorsy country & .905 \\
\hline & Turkey is a rebel country & .499 \\
\hline & Turkey is a rugged country & .825 \\
\hline
\end{tabular}

\section{FINDINGS}

In the findings section, demographic characteristics and Paired Sample T Test analysis results are given. Before the findings were obtained, the normality test was performed and the $\mathrm{p}$ value was found to be 0.000 at the end of the test. According to this result, the sample is not suitable for normal distribution; however, the coefficients of skewness (0.717) and kurtosis (0.735) have values between 1.5 and +1.5 and according to these values, the sample was assumed to be suitable for normal distribution.

\subsection{Demographic Findings}

Information on the demographic characteristics of the survey participants is presented in Table 3. In the surveys in both periods, the proportion of males is higher than females, the proportion of married people is higher than singles, the proportion of those between the ages of 35-44 is higher than other age ranges, the proportion of those who have a university education is higher than other education levels, the proportion of those doing a job that requires expertise (such as doctor, engineer, lawyer, 
academician) is higher than other professionals, the proportion of those with an income level of $\$ 3001$ 4500 is higher than those with an income level of other.

Table 3. Demographic Characteristics of the Sample

\begin{tabular}{|c|c|c|c|c|c|}
\hline \multirow{2}{*}{ VARIABLE } & \multirow{2}{*}{ GROUP } & \multicolumn{2}{|c|}{ Pre Test } & \multicolumn{2}{|c|}{ Post Test } \\
\hline & & $\mathbf{N}$ & $\%$ & $\mathbf{N}$ & $\%$ \\
\hline \multirow{2}{*}{ GENDER } & Female & 146 & 38.6 & 121 & 36.1 \\
\hline & Male & 232 & 61.4 & 214 & 63.9 \\
\hline \multirow{2}{*}{$\begin{array}{l}\text { MARITAL } \\
\text { STATUS }\end{array}$} & Married & 256 & 67.7 & 213 & 63.6 \\
\hline & Single & 122 & 32.3 & 122 & 36.4 \\
\hline \multirow{5}{*}{ AGE RANGE } & $18-24$ & 28 & 7.4 & 21 & 6.2 \\
\hline & $25-34$ & 125 & 33.1 & 114 & 34 \\
\hline & $35-44$ & 194 & 51.3 & 180 & 53.8 \\
\hline & $45-54$ & 17 & 4.5 & 10 & 3 \\
\hline & +55 & 14 & 3.7 & 10 & 3 \\
\hline \multirow{5}{*}{ EDUCATION } & Primary School & - & - & - & - \\
\hline & Secondary School & - & - & - & - \\
\hline & High School & 28 & 7.4 & 18 & 5.4 \\
\hline & University & 210 & 55.6 & 142 & 42.4 \\
\hline & Postgraduate & 140 & 37.0 & 175 & 52.2 \\
\hline \multirow{9}{*}{ JOB } & Worker-Farmer & 28 & 7.4 & 22 & 6.5 \\
\hline & Student & 42 & 11.1 & 41 & 12.2 \\
\hline & Manager & 42 & 11.1 & 30 & 8.9 \\
\hline & Expert* & 126 & 33.3 & 114 & 34 \\
\hline & Artisan-Merchant & 14 & 3.7 & 12 & 3.6 \\
\hline & Unemployed & 28 & 7.4 & 23 & 6.9 \\
\hline & Other & 11 & 2.9 & 9 & 2.8 \\
\hline & Officer & 87 & 23.1 & 84 & 25.1 \\
\hline & Housewife & - & - & - & - \\
\hline \multirow{7}{*}{ INCOME (ח) } & -Minimum Wage & 56 & 14.8 & 41 & 12.2 \\
\hline & Minimum Wage & 42 & 11.1 & 41 & 12.2 \\
\hline & Minimum Wage-1500 & 28 & 7.4 & 22 & 6.6 \\
\hline & $1501-3000$ & 56 & 14.8 & 55 & 16.4 \\
\hline & $3001-4500$ & 126 & 33.3 & 123 & 36.7 \\
\hline & $4501-6000$ & 56 & 14.8 & 40 & 12 \\
\hline & +6000 & 14 & 3.8 & 13 & 3.9 \\
\hline
\end{tabular}

* Doctor, engineer, lawyer, academician, etc. 


\subsection{Paired Samples T Test}

Paired Samples T Test is used to determine whether there is a statistically significant difference between the pre-test and post-test scores of the individuals in the experimental group (Koparan and Güven 2013: 190). In this study, two groups were formed to test the before-after relationship (September 2020 group and December 2020-January 2021 group) and it was tried to see whether there was a significant difference in the means in the comparison of these two groups.

As seen in Table 4, there is a significant difference between the groups for all dimensions; but considering the mean of the dimensions, the mean for the "ruggedness" dimension is lower for the posttest. Post-test means are higher in all dimensions except this dimension. Therefore, all hypotheses except H5 hypothesis can be accepted.

Table 4. Paired Samples T Test Results

\begin{tabular}{|c|c|c|c|c|c|c|}
\hline \multicolumn{2}{|l|}{ Dimension } & $\mathbf{N}$ & $\overline{\mathbf{X}}$ & $\Sigma$ & $\mathbf{t}$ & $\mathbf{P}$ \\
\hline \multirow{2}{*}{ Sincerity } & Pre Test & 378 & 3.7597889 & .05109903 & \multirow[t]{2}{*}{-12.801} & \multirow{2}{*}{.000} \\
\hline & Post Test & 335 & 3.9750000 & .00229129 & & \\
\hline \multirow{2}{*}{ Excitement } & Pre Test & 378 & 3.7037400 & .00002739 & \multirow{2}{*}{-99835.409} & \multirow{2}{*}{.000} \\
\hline & Post Test & 335 & 3.9919400 & .00002739 & & \\
\hline \multirow{2}{*}{ Competence } & Pre Test & 378 & 4.0142089 & .00001167 & \multirow[t]{2}{*}{-44833.339} & \multirow{2}{*}{.000} \\
\hline & Post Test & 335 & 4.2813111 & .00001537 & & \\
\hline \multirow{2}{*}{ Sophistication } & Pre Test & 378 & 3.5648111 & .00001537 & \multirow{2}{*}{-21175.839} & \multirow{2}{*}{.000} \\
\hline & Post Test & 335 & 3.7377111 & .00001537 & & \\
\hline \multirow{2}{*}{ Ruggedness } & Pre Test & 378 & 3.6203978 & .00003114 & \multirow{2}{*}{3290.086} & \multirow{2}{*}{.000} \\
\hline & Post Test & 335 & 3.5817100 & .00001803 & & \\
\hline \multirow{2}{*}{ Scale } & Pre Test & 378 & 3.7326 & .15922 & \multirow{2}{*}{-10.096} & \multirow{2}{*}{.000} \\
\hline & Post Test & 335 & 3.9135 & .24196 & & \\
\hline
\end{tabular}

The decisions regarding the research hypotheses are presented in Table 5. According to the Paired Samples T Test results in Table 4, the post test means of all hypotheses except H5 hypothesis is higher and this difference is significant. In addition, the post test mean in the means taken for the scale is greater than the first test mean and this result is also significant according to the $p$ value. Based on this, all hypotheses can be accepted except the H5 hypothesis of the research. 
Table 5. Decisions Regarding the Research Hypotheses

\begin{tabular}{|l|c|}
\hline Hypothesis & Decision \\
\hline $\begin{array}{l}\text { H1: Turkey's image in the eyes of the Azerbaijani people showed a significant difference } \\
\text { in a positive (increased) direction after the war in "sincerity" dimension. }\end{array}$ & $\checkmark$ \\
\hline $\begin{array}{l}\text { H2: Turkey's image in the eyes of the Azerbaijani people showed a significant difference } \\
\text { in a positive (increased) direction after the war in "excitement" dimension. }\end{array}$ & $\checkmark$ \\
\hline $\begin{array}{l}\text { H3: Turkey's image in the eyes of the Azerbaijani people showed a significant difference } \\
\text { in a positive (increased) direction after the war in "competence" dimension. }\end{array}$ & $\checkmark$ \\
\hline $\begin{array}{l}\text { H4: Turkey's image in the eyes of the Azerbaijani people showed a significant difference } \\
\text { in a positive (increased) direction after the war in "sophistication" dimension. }\end{array}$ & $\checkmark$ \\
\hline $\begin{array}{l}\text { H5: Turkey's image in the eyes of the Azerbaijani people showed a significant difference } \\
\text { in a positive (increased) direction after the war in "ruggedness" dimension. }\end{array}$ & X \\
\hline $\begin{array}{l}\text { H6: Turkey's image in the eyes of the Azerbaijani people showed a significant difference } \\
\text { in a positive (increased) direction after the war for the "brand image" scale. }\end{array}$ & $\checkmark$ \\
\hline
\end{tabular}

\section{CONCLUSION AND RECOMMENDATIONS}

Turkey and Azerbaijan are two brotherly countries including important historical, religious, cultural and ethnic ties. Therefore, the relationship between the two countries is seen as a strategic partnership and has progressed even faster, especially since Azerbaijan declared its independence in 1991. There is a lot in common in the interests of these two brother countries and these common points further increase their strategic cooperation. The special bond between the two countries finds its place in the discourses of Mustafa Kemal Atatürk and Heydar Aliyev, and it makes the views of these two countries towards each other positive and strong.

The strong image of a country in the eyes of foreign people is a very positive situation for that country. Perceptions, attitudes, beliefs, positive associations and emotional ties about that country can be established with the activities of a country. Thus, a strong image of a country can be determinant in the emergence of attitudes and behaviours towards that country and there are many factors influencing the formation of this image. If the image of the country is positive and in the desired direction, this can instil the impression, opinion and belief to the citizens of foreign countries that it is a good country.

The initial aim of this study is to determine Turkey's brand image in the eyes of Azerbaijan; however, with the start of the Azerbaijan-Armenia war, the survey application of the study (due to restrictions on internet access throughout Azerbaijan) had to stop. Afterwards, the war ended in favour of Azerbaijan and with the re-opening of internet access, the survey application continued where it left off. But this time the purpose of the previous study was amended and it was aimed to see if it is having a significant difference in the brand image of Turkey the eyes of Azerbaijan before and after the war. One of the scales frequently used in measuring the image of a country's brand is the Dimensions of Brand Personality scale developed by Aaker in 1997. This scale, which reflects Aaker's brand 
personality, was later used in subjects such as brand image and country brand image. In the current study, it is tried to reach the aim of the study by using the dimensions of the scale (excitement, sincerity, sophistication, competence, and ruggedness).

When looking at the findings of the research, the most important test to be considered is the Paired Samples T Test results. Whether the research's hypotheses are supported or not is revealed by this test. According to the test results, the hypotheses were supported for the whole scale and all dimensions except the "robustness" dimension. Hence, it can be inferred that Turkey impression (image) of the people of Azerbaijan was strengthened after Azerbaijan-Armenia war. After the war, the citizens of Azerbaijan sees Turkey as a more sincere, excited, competent and sophisticated country. On the other hand, there is a regression in the "robustness" point. By looking at the items of the aforementioned dimension, "struggling" (pre-test mean: 4.33 and post-test mean: 4.64), "strong" (pre-test mean: 4.22 and post-test mean: 4.55), "extrovert "(pre-test mean: 3.26 and post-test mean: 3.55), "rebellious" (pretest mean: 2.93 and post-test mean: 3.18 ) and "resistant"(pre-test mean: 4.26 and post-test mean: 4.27) items are in favour of Turkey and; "masculine" (pre-test mean: 3.56 and post-test mean: 3.37), "hard" (pre-test mean: 3.48 and post-test mean: 2.19) and "western" (pre-test mean: 2.93 and post-test (mean: 2.91) items are in opposite situation.

As we have seen, in five of the eight items are in favour of Turkey in the post-war situation. As we have seen, in five of the eight items are in favour of Turkey in the post-war situation. Therefore, a lower result was obtained in the general mean of the dimension. The decrease in "Western" item will be the reason of the diplomatic language arising from Turkey's upright posture in relation between Turkey and West (especially the US and EU).

However, the decrease in the perception of these two items, such as "masculine" and "hard", which have high correlation with each other, is a point that needs to be examined and is proposed as a new research topic. However, it should not be forgotten that the results presented here are only interpreted in the light of the data obtained from the survey participants and no generalization is made for all Azerbaijanis.

\section{REFERENCES}

Aaker, Jennifer (1997). "Dimensions of brand personality”. Journal of Marketing Research 34(3): 347-356.

Aksoy, Ersin (2008). Ülkelerin ve Coğrafi Bölgelerin Markalaşması. Türk Patent Enstitüsü Markalar Dairesi Başkanlığ1, Uzmanlık Tezi, Ankara.

Altan, Ahmet (2006). “Şeriatın Başkenti... Bugün İstanbul Yok”. https://www.hurriyet.com.tr/seriatin-baskenti-bugunistanbul-yok-4984922 (Access: 14.08.2020).

Aslan, Ramazan and Özbeyaz, Abdurrahamn. (2019). Satın Alma Sürecinde Marka Bağımlılı̆̆ı Üzerine Bir Araştırma: Adıyaman Üniversitesi Örneği. Insan ve Toplum Bilimleri Araştırmaları Dergisi, 8 (3), 1967-1990.

Aslanlı, Araz (2012), “Karabağ Sorunu ve Azerbaycan-Türkiye-Ermenistan İlişkileri”. Çankırı Karatekin Üniversitesi Uluslararasi Avrasya Strateji Dergisi 1(1): 175-196.

Aslanl1, Araz (2018). "Türkiye-Azerbaycan Ekonomik İlişkileri”. Yönetim ve Ekonomi 25(1): 15-27.

Aydın, Ulviyye (2018). "Türkiye-Azerbaycan İlişkilerinin Son On Y1lı (2006-2016): Kardeşlikten Stratejik İşbirliğine Uzanan Yol”. Avrasya Uluslararast Araştırmalar Dergisi 6(13): 38-62. 
Baş, Mehmet (2020). Marka Yönetimi. Ankara: Detay Yay.

Chiang, Luke and Chin-Sheng Yang (2018). "Does country-of-origin brand personality generate retail customer lifetime value? A Big Data analytics approach”. Technological Forecasting \& Social Change 130: 177-187.

Demir, Ergül et al. (2016). "Uluslararası Dergilerde Yayımlanan Eğitim Araştırmalarının Normallik Varsayımları Açısından İncelenmesi”. Current Research in Education 2(3): 130-148.

Dündar Kurtuluş, Sema (2008). "Ülkelerin Marka Kişiliği Üzerine Bir Araştırma". Atatürk Üniversitesi İktisadi ve İdari Bilimler Dergisi 22(2): 285-300.

Feldwick, Paul (2002). What is Brand Equity, Anyway?. UK: NTC Publications.

Gültekin, Bilgehan (2005). “Türkiye’nin Uluslararası İmajında Yükselen Değerler”. Selçuk İletişim 4 (1): 126-140.

Pazarlama30.com (2020). https://www.pazarlama30.com/art_k-ulkeler-de-b_rer-marka-nat_on-brand_ng-ulus-markalasmas_/ (Access: 01.02.2021).

İnanç, Hüsamettin and İbrahim Yacan (2018). “Ülkelerin Markalaşma Süreci ve Marka Kavramı”. Uluslararası Yönetim Akademisi Dergisi 1(3): 317-331.

Karadağ, Sinem and Gözde Top (2012). Duygusal birliktelikten stratejik ortaklığa Türkiye Azerbaycan ilişkileri. Santra İstanbul: Küresel Sorunlar Platformu.

Kılıç, Selim (2016). “Cronbach’ın Alfa Güvenirlik Katsayısı”. Journal of Mood Disorders 6 (1): 47-48.

Koparan, Timur and Bülent Güven (2013). "Proje Tabanlı Öğrenme Yaklaşımının İlköğretim Öğrencilerinin Örneklem Kavramına Yönelik İstatistiksel Okuryazarlık Seviyesine Etkisi”. Eğitim ve Öğretim Araştırmaları Dergisi 2(1): 186196.

Kotler, Philip and Kevin Lane Keller (2006). Marketing Management. 12th Ed., USA: Prentice Hall.

Mariutti, Fabiana Gondim and Janaina de Moura Giraldi (2020). “Country brand personality of Brazil: a hindsight of Aaker's theory". Place Branding and Public Diplomacy 16: 251-264.

Méndez, Jose et al. (2013). “The U.S. brand personality: A Sino perspective”. Journal of Business Research 66: 1028-1034.

Mesimov, Ali (2001). "Bağımsızlık Yıllarında Azerbaycan-Türkiye İlişkileri”. Avrasya Dosyası, Azerbaycan Özel 7(1): 274285.

Onay, Atılım (2008). “Ülke Orijini Kavramı ve Ülke İmajı”. Selçuk İletişim 5(2): 102-112.

Özenç, Hakan (2002). “Türkiye’nin İmaj Sorunu ve İhracat”. KalDer Forum Dergisi 2(8): 38-45.

Pitt, Leyland F. et al. (2007). "What I say about myself: Communication of brand personality by African countries". Tourism Management 28: 835-844.

Priporas, Constantinos-Vasilios et al. (2020). "City image, city brand personality and generation Z residents' life satisfaction under economic crisis: Predictors of city-related social media engagement”. Journal of Business Research 119: 453463.

Queiroz, Livia and Janaina M.E. Giraldi (2015). "Country brand equity: a comparison between the USA and China”. Rev. Bus. Manag. 17(57): 1193-1211.

Veliyev, Cavid (2020). Azerbaycan-Türkiye Stratejik Ortaklı̆̆ı. İstanbul: Ötüken Yay.

Veliyev, Cavid et al. (2012). Azerbaycan-Türkiye: Dostluk, Kardeşlik ve Strateji Ortaklık. Ankara: Berikan Yay.

\section{ARAŞTIRMANIN ETIK İZNi}

Yapılan bu çalışmada "Yükseköğretim Kurumları Bilimsel Araştırma ve Yayın Etiği Yönergesi” kapsamında uyulması gerektiği belirtilen tüm kurallara uyulmuştur. Yönergenin ikinci bölümü olan "Bilimsel Araştırma ve Yayın Etiğine Aykırı Eylemler" başlığı altında belirtilen eylemlerden hiçbiri gerçekleştirilmemiştir.

\section{Etik kurul izin bilgileri}

Etik değerlendirmeyi yapan kurul adı: T.C. Bayburt Üniversitesi Etik Kurulu

Etik değerlendirme kararının tarihi: 04.09.2020

Etik değerlendirme belge sayıs1: 2020/77 


\begin{tabular}{|c|c|c|}
\hline $\begin{array}{l}\text { KATKI ORANI / } \\
\text { CONTRIBUTION RATE }\end{array}$ & $\begin{array}{l}\text { AÇIKLAMA / } \\
\text { EXPLANATION }\end{array}$ & $\begin{array}{l}\text { KATKIDA BULUNANLAR / } \\
\text { CONTRIBUTORS* }\end{array}$ \\
\hline $\begin{array}{l}\text { Fikir veya Kavram / Idea or } \\
\text { Notion }\end{array}$ & $\begin{array}{l}\text { Araştırma hipotezini veya } \\
\text { fikrini oluşturmak / Form the } \\
\text { research hypothesis or idea }\end{array}$ & $\begin{array}{l}\text { Bora GÖKTAŞ } \\
\text { İnci ERDOĞAN TARAKÇI } \\
\text { Mehmet BAŞ }\end{array}$ \\
\hline Tasarım / Design & $\begin{array}{l}\text { Yöntemi, ölçeği ve deseni } \\
\text { tasarlamak / Designing method, } \\
\text { scale and pattern }\end{array}$ & $\begin{array}{l}\text { Bora GÖKTAŞ } \\
\text { İnci ERDOĞAN TARAKÇI } \\
\text { Mehmet BAŞ }\end{array}$ \\
\hline $\begin{array}{l}\text { Veri Toplama ve İşleme / Data } \\
\text { Collecting and Processing }\end{array}$ & $\begin{array}{l}\text { Verileri toplamak, } \\
\text { düzenlenmek ve raporlamak / } \\
\text { Collecting, organizing and } \\
\text { reporting data }\end{array}$ & $\begin{array}{l}\text { Bora GÖKTAŞ } \\
\text { İnci ERDOĞAN TARAKÇI } \\
\text { Mehmet BAŞ }\end{array}$ \\
\hline $\begin{array}{l}\text { Tartışma ve Yorum / } \\
\text { Discussion and Interpretation }\end{array}$ & $\begin{array}{l}\text { Bulguların } \\
\text { değerlendirilmesinde ve } \\
\text { sonuçlandırılmasında } \\
\text { sorumluluk almak / Taking } \\
\text { responsibility in evaluating and } \\
\text { finalizing the findings }\end{array}$ & $\begin{array}{l}\text { Bora GÖKTAŞ } \\
\text { İnci ERDOĞAN TARAKÇI } \\
\text { Mehmet BAŞ }\end{array}$ \\
\hline $\begin{array}{l}\text { Literatür Taramas1 / Literature } \\
\text { Review }\end{array}$ & $\begin{array}{l}\text { Çalışma için gerekli literatürü } \\
\text { taramak / Review the literature } \\
\text { required for the study }\end{array}$ & $\begin{array}{l}\text { Bora GÖKTAŞ } \\
\text { İnci ERDOĞAN TARAKÇI } \\
\text { Mehmet BAŞ }\end{array}$ \\
\hline
\end{tabular}

Hakem Değerlendirmesi: Dış bağımsız.

Çıkar Çatışması: Yazar çıkar çatışması bildirmemiştir.

Finansal Destek: Yazar bu çalışma için finansal destek almadığını beyan etmiştir.

Teşekkür: -

Peer-review: Externally peer-reviewed.

Conflict of Interest: The author has no conflict of interest to declare.

Grant Support: The author declared that this study has received no financial support.

Acknowledgement: - 